\title{
PCCS トーンにおける色相と印象の関係性の検討
}

\author{
○若田忠之・齋藤美穂 \\ (早稲田大学人間科学学術院) \\ キーワード : PCCS、トーン、色彩印象
}

A study of relationship between hue and color emotion in PCCS tone.

Tadayuki WAKATA and Miho SAITO

(Faculty of human sciences, Waseda University)

Key Words: PCCS, tone, color emotion

\section{目 的}

本研究で扱うPCCS (Practical Color Co-ordinate System) は、色を管理する表色系の1つである。色の表現については 3 属性が明らかになっており、PCCS においても色相、明度、 彩度の 3 つの属性で色を表すことができる。3 属性について は、完全に独立ではなく、へルムホルツ - コールラウシュ効 果 $(H-K$ 効果) として、特に明度と彩度の間に相関関係が認め られることが明らかになっている。PCCS においては、明度と 彩度を組み合わせた「トーン」という概念をもつことが特徴 的な点であることから、本研究ではこの表色系に着目した。 トーンの特徴の一つに色相が異なっても同一のトーンであれ ば印象が類似するという点があげられる。そこで、本研究で は同一トーンで構成された 5 色の色相環を提示した際に、各 色相がトーンに与える影響の関連性について検討することを 目的とした。

\section{方 法}

刺激:色については、PCCSにおける全 12 トーンから $2 \mathrm{R} 、 8 \mathrm{Y} 、$ 12G、18B、22P の 5 色相および無彩色 5 色 (W、7.5Gy、5.5Gy、 3. $5 \mathrm{~Gy}$ 、Bk）の計 65 色を用いた。トーン刺激は、各トーンを 5 色相の色相環とした (各色 : $3 \mathrm{~cm} \times 3 \mathrm{~cm}$ ) 12 個、色相刺激は色 相ごとに 12 トーンを並列に配置した (各色 : $1.5 \mathrm{~cm} \times 3 \mathrm{~cm}$ ) 5 個、無彩色刺激は 5 色の無彩色を並列に配置した (各色: 1.5 $\mathrm{cm} \times 3 \mathrm{~cm}) 1$ 個、個別刺激は 1 色ずつ $(3 \mathrm{~cm} \times 3 \mathrm{~cm})$ とした 65 個 を用いた。刺激数は合計 83 刺激であった。これらの色はニュ 一トラルグレイの台紙に貼り付けて提示した(図 1)。

質問紙: 7 段階 15 形容詞対で構成した SD 法および、Visual Analog Scale(VAS) を用いた 2 項目 (明るい一暗い、あざやか -くすんだ)の計 17 項目とし、iPad 上に提示した。形容詞対 については、大山(2001)、Wakata\&Saito(2012)より選定した。

実験参加者: 30 名の成人男女（男女比 8:22、平均 $21.6 \pm 2.0$ 歳)が実験に参加した。

手続き:刺激はランダムな順で提示され、参加者は提示され た刺激について SD 法、VAS の質問紙に回答した。実験環境は、 標準的な蛍光灯下で行った。

\section{結 果}

本研究では、SD 法の印象評価に着目して分析を行った。

因子分析:印象次元を抽出するために、全ての刺激における $\mathrm{SD}$ 法印象評価に対して因子分析 (最尤法、プロマックス回転) を行った。その結果、4 因子が得られた(表 1,2)。

重回帰分析: 因子得点で得られた因子得点を分析対象のデー タとし、各色相の関係性に着目寸るため強制投入法を用いた。 トーン刺激を従属変数、トーンを構成する 5 つの色相を独立 変数とした重回帰分析を行った。分析は、12 のトーンごとに 4 つの因子について行ったため、計 48 の回帰式が得られた。 得られた回帰式の中から有意であった式を抜粋したものを表 3 に示す。

$$
\text { tone }=2 \mathrm{R}+8 \mathrm{Y}+12 \mathrm{G}+18 \mathrm{~B}+22 \mathrm{P}+\mathrm{e}
$$

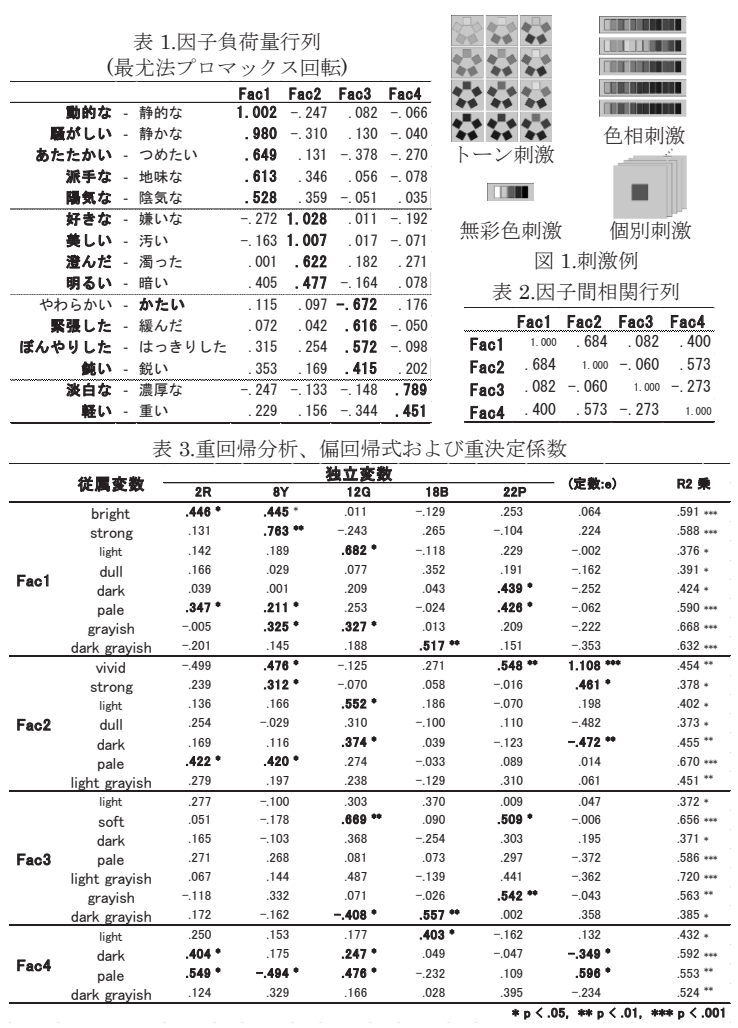

\section{考 察}

因子分析結果については、項目を参照した先行研究との比 較から第 1 因子は活動性、第 2 因子は力量性と軽明性が混在 した因子、第 3 因子は大山 (2001) における鋭さ因子、第 4 因 子はWakata\&Saito(2012) でも同様の傾向がみられたことから、 トーンにみられるような、色の濃淡に関連した因子であると 考えられる。

重回帰分析結果については、第 4 因子では相対的に有意な 式が得られるトーンが少ないことから、色相の違いに影響を 受けにくい印象次元であると考えられる。結果全体について、 それぞれの式の中で偏回帰係数が高い色相が一定ではない傾 向がみられた。この点から、影響の強さはトーンによって異 なることが示唆された。

\section{引用文献}

大山正 (2001), 色彩調和か配色効果か一心理学の立場から-, 日本色彩学会, 25(4), 283-287. T. Wakata and M. Saito(2012), The impression of tones and hue in gradation of Practical Color Co-0rdinate System (PCCS), International Color Association 2012 Taipei, 322-325 